\title{
Reformulation of vermicast as organic fertilizer for corn (Zea mays L.)
}

Mark Anthony M. Barbadillo', Renante G. Macapanas ${ }^{2}$ and Romel B. Armecin ${ }^{23 *}$

The increasing demand for healthy and sustainable food production practices has encouraged farmers to switch to the use of organic fertilizers. Information on the nutrient composition of the available organic products is minimal. Hence, this study was conducted to survey and collect samples of vermicast fertilizer materials in Western Visayas and do reformulation work to improve the nutrient composition and perform efficacy trials for corn seedling at the early stage of growth. Among the collected samples, soil $\mathrm{pH}$ values ranged from 4.7-7.0, OM from $25.40-45.40 \%$, and total $\mathrm{N}, \mathrm{P}, \mathrm{K}, \mathrm{Na}$, $\mathrm{Ca}$ and $\mathrm{Mg}$ contents ranged from $0.70-1.40 \%, 0.04-0.90 \%, 0.30-1.00 \%, 0.03-0.17 \%, 1.30-$ $2.60 \%$, and $0.50-0.80 \%$, respectively. Reformulated vermicasts contained high total $\mathrm{N}$ content (1.23-1.37\%) but had lower total P, K, Na, Ca and Mg contents than most vermicasts from Western Visayas. The plant height, leaf area and dry matter yield of the corn seedlings using the reformulated vermicast was significantly higher than those seedlings treated with inorganic fertilizer.

Keywords: organic fertilizer, corn, dry matter yield, reformulation, vermicast

\section{INTRODUCTION}

Organic agriculture has long been used as a healthy, alternative way of producing crops for human consumption. The practice promotes the use of organicbased pesticides and fertilizer formulations rather than synthetic chemicals for managing farm problems. Organic fertilizer functions to reduce soil acidity, improve soil structural stability, and supply nutrients for plant growth and development that are released gradually. Continuous application of organic fertilizer not only reduces the fertilizer cost, but also improves soil quality and maintains soil $\mathrm{N}, \mathrm{P}$, and $\mathrm{K}$

\footnotetext{
${ }^{1}$ Department of Soil Science, Visayas State University, Baybay City, Leyte 6521-A

${ }^{2}$ Ecological Farm and Resource Management Institute, Visayas State University, Baybay City, Leyte 6521-A ${ }^{2}$ National Abaca Research Center, Visayas State University, Baybay City, Leyte 6521-A
}

\footnotetext{
*Corresponding Author. Address: Ecological Farm and Resource Management Institute, Visayas State University, Baybay City, Leyte6521-A; Email: rbarmecin@vsu.edu.ph
} 
content (de la Cruz et al 2008). Organic fertilizers can be in liquid or granulated forms of either plant, animal and mineral-based origin. Among the organic fertilizers known, vermicast, an end product of organic matter breakdown by earthworms and other microorganisms, has a potential for crop yield improvement and has been commonly used by farmers throughout the Philippines.

Vermicast is considered as a common organic fertilizer with a fine and wellstabilized structure, high water-holding capacity with diverse microbial and enzymatic reactions, which is capable of retaining readily available forms of $N, P, K$ and $\mathrm{Mg}$ (Aviles 2010). Priya and Santhi (2014) stated that, amaranthus plants treated with vermicast showed better results than the control samples with relatively higher soil N, P, K, Fe, Mn, Zn and Cu content. Moreover, Karmegam and Daniel (2009) added that elevated levels of N, P and K in vermicast initiate earlier rooting and better root development of Codiaeum variegatum when compared to untreated plants. As the benefits from using organic-based fertilizers become more evident, the use of beneficial microorganisms in organic fertilizer production has also been introduced and has been used for a wide variety of crops, including corn (Hafiz et al 2020, Aboukila et al 2018, Deshev et al 2020).

Corn is (Zea mays L.), also known as maize, is an annual herbaceous tropical plant. It was one of the first cereals to be cultivated before rice and wheat. It has been planted throughout the world as forage, food and industrial crops. In the Philippines, about one-third of the Filipino farmers have been cultivating corn, making it the second most important crop next to rice. It has been used as a staple food and has been consumed mostly by people in the marginal uplands of North and Eastern Luzon, Central and Eastern Visayas, and Northern and Western Mindanao (Lina et al 2014).

Several studies on the growth of corn with different organic fertilizers have been documented, but these use different substrates in their formulation process. Likewise, the knowledge regarding the chemical composition of the material used as an amendment to crops is very limited. Hence, this study was conducted to: (1) determine the chemical composition of vermicasts from Western Visayas, (2) reformulate a vermicast-based organic fertilizer to simplify the mix that has the potential for commercialization, and (3) conduct an efficacy test on corn plants at the early stage of growth.

\section{MATERIALS AND METHODS}

\section{Collection, Preparation and Analysis of Fertilizer Materials}

Vermicasts were collected from selected farms in Western Visayas (Figure 1). Samples were air-dried, pulverized and were allowed to pass through a $2 \mathrm{~mm}$ sieve for $\mathrm{pH}$ and total $\mathrm{P}, \mathrm{K}, \mathrm{Na}, \mathrm{Ca}$ and $\mathrm{Mg}$ analysis, and a $0.425 \mathrm{~mm}$ sieve for the total $\mathrm{N}$ and organic matter (OM) analysis. Soil pH was determined potentiometrically at 1:2.5 soil to water ratio (PCARR 1980). The OM content was determined by the Modified Walkley-Black method (Nelson and Sommers 1982). The total $\mathrm{N}$ was analysed following the micro-Kjeldahl Method (ISRIC 2002), P using the Vanadomolybdate Method, $\mathrm{K}$ and $\mathrm{Na}$ using Flame Atomic Emission Spectroscopy (FAES) Method, and Ca and Mg using the Atomic Absorption Spectrophotometer (AAS) Method (BSWM 2014). The result of the analysis served as a guide to compare the quality and nutrient composition with the reformulated product. 


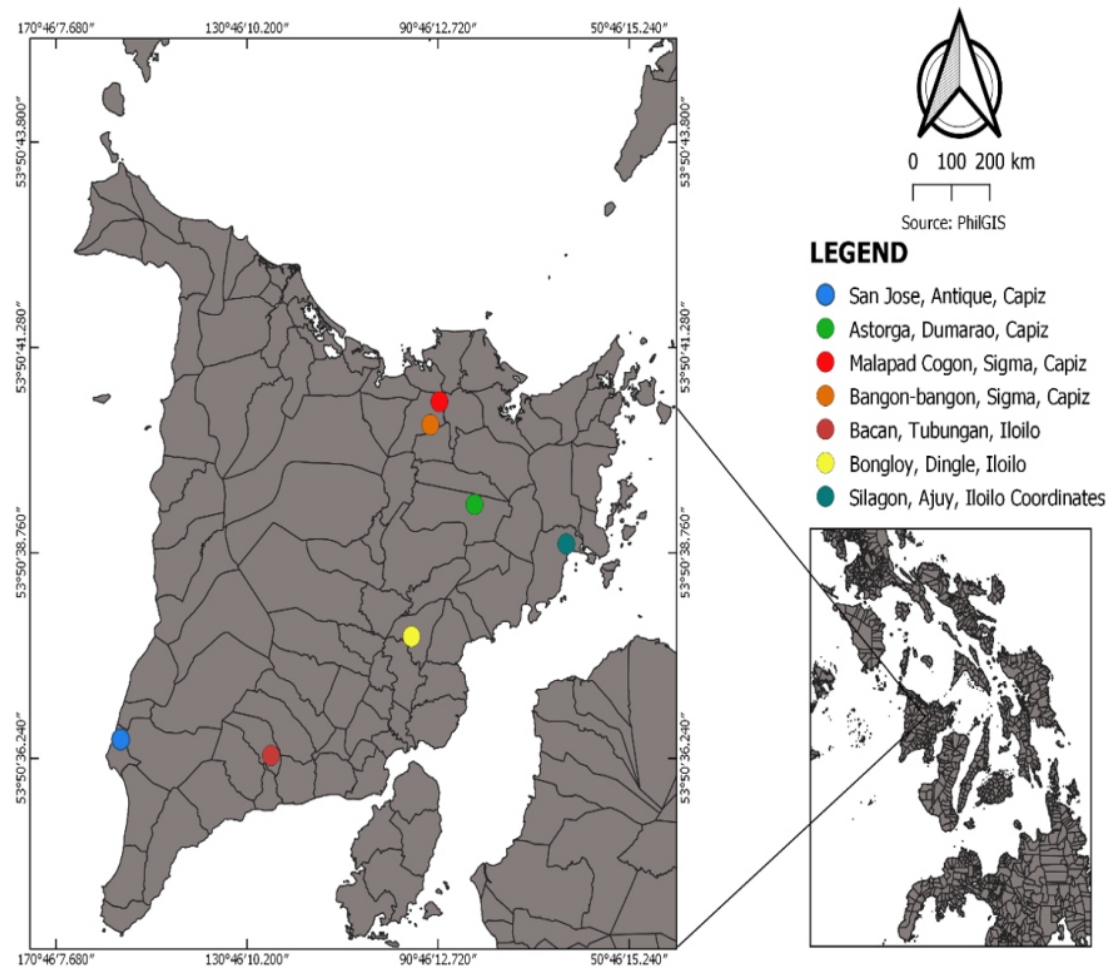

B.

Figure 1. Sampling areas in Western Visayas (Areas are arranged accordingly with code numbers from 1-7)

\section{Vermicast Reformulation and Inoculation}

Vermicomposting was conducted at the demonstration farm of the Ecological Farm and Resource Management Institute (Eco-FARMI), Visayas State University (VSU), Visca, Baybay City, Leyte. The set-up involved two (2) mudpress-based substrates: Organic Fertilizer ${ }_{1}\left(\mathrm{OF}_{1}\right)$ consisting of mudpress + cow manure + banana peelings + Lactic acid bacteria serum (LABS) extract, and Organic Fertilizer ${ }_{2}$ $\left(\mathrm{OF}_{2}\right)$ comprised of mudpress + madre de cacao + rice straw + LABS, and were replicated three (3) times. Substrates were mixed at a ratio of 2:2:1 on dry weight basis. After partial decomposition of the different substrates in concrete hollow block boxes measuring $1 \times 1 \times 0.3 \mathrm{~m}$, length, width and height, respectively, $500 \mathrm{~g}$ of earthworms (Eudrilus euginiae) were added to each designated box. Likewise, $80 \mathrm{~mL}$ of pure LABS extract was sprayed uniformly onto the surface of each experimental unit. The cast was collected after a month of the vermicomposting process or until the raw materials were fully transformed into cast. Analyses of the $\mathrm{pH}, \mathrm{OM}$, and total $\mathrm{N}, \mathrm{P}, \mathrm{K}, \mathrm{Na}, \mathrm{Ca}$ and $\mathrm{Mg}$ content of the reformulated vermicasts were done. These were compared to all the analyses obtained from the average data of the seven (7) collected samples from Western Visayas, as a guide in determining if the quality of the reformulated fertilizer material was improved. 


\section{Pot Preparation and Efficacy Test}

Garden soil that had passed through a $2 \mathrm{~mm}$ sieve was mixed thoroughly with rice hull at a ratio of 2:1 as the base potting media for both the control and inorganic fertilizer treatments. However, in the different organic fertilizer treatments, the potting media were prepared with the addition of 1 part organic fertilizer resulting in a 2:1:1 ratio of garden soil, rice hull, and organic fertilizer, respectively.

The efficacy test was conducted at the screenhouse of the National Abaca Research Center (NARC), VSU, Visca, Baybay City, Leyte. Pots were arranged in a Completely Randomized Design (CRD) with five (5) treatments: $T_{1}$ - garden soil + rice hull (control), $T_{2}-$ garden soil + rice hull + inorganic fertilizer, $\mathrm{T}_{3}-$ garden soil + rice hull + EM (effective microorganisms) $T_{4}$ - garden soil + rice hull $+\mathrm{OF}_{1}$, and $\mathrm{T}_{5}-$ garden soil + rice hull $+\mathrm{OF}_{2}$, and were replicated four (4) times. EM is a rice bran-based material using the LABS extract as the source of beneficial organisms in the organic fertilizer material. EM was produced by sprinkling $15 \mathrm{~L}$ of the diluted LABS extract (ie, 1:100 ratio of LABS to water) onto $25 \mathrm{~kg}$ of rice bran. After mixing, the soaked rice bran was allowed to incubate for a period of 7 days until cold enough to serve as fertilizer material.

Equal amounts of prepared medium was placed in $15 \mathrm{~cm}$ diameter pots and planted with corn seeds (Var. Macho F1). The inorganic fertilizer application (ie, urea, solophos and muriate of potash) was based on the recommended rate for corn (90-60-60kg N, $\mathrm{P}_{2} \mathrm{O}_{5}, \mathrm{~K}_{2} \mathrm{O} \mathrm{ha}^{-1}$ ). Growth parameters (ie, number of leaves, plant height and leaf area) were gathered every other week, while the dry matter yield for each pot was determined right after the termination of the study at 21 days after sowing (DAS).

\section{Data Analysis}

Data gathered were analyzed using the Statistical Tool for Agricultural Research (STAR) software version 2.0.1. Analysis of variance (ANOVA) was used to test the significant effects among treatments and was compared using Least Significant Difference (LSD) at a $5 \%$ level of significance.

\section{RESULTS AND DISCUSSION}

\section{Chemical Composition of Collected Vermicasts}

The nutrient composition of organic fertilizers varies depending on the type and composition of raw materials used. The average percentage of raw materials used to make vermicasts collected in Western Visayas, as reported by farmers, was mostly animal manure (24\%), market wastes (19\%), mudpress (15\%), rice straw (15\%) and rice hull (14\%) (Figure 2). Farmers usually use raw materials for composting that are present within or near the vicinity of their farms. On the other hand, for the chemical composition, relatively higher $\mathrm{pH}, \mathrm{OM}$ and total $\mathrm{N}, \mathrm{P}, \mathrm{K}, \mathrm{Na}, \mathrm{Ca}$ and $\mathrm{Mg}$ content was observed in vermicasts derived from animal manures and mudpress (ie, samples 1, 4, 5, 6, and 7) (Table 1). 
The average analysis of these vermicast samples also served as the reference sample (RS) in the comparative analysis presented in Figure 3. The $\mathrm{pH}$ of the vermicast samples ranged from 4.7-7.0. The substrates used in the composting process are non-acid forming thus, keeping the $\mathrm{pH}$ values at near-neutral. OM contents of the samples ranged from $25.40-45.40 \%$. The total N, P, K, Na, Ca and $\mathrm{Mg}$ content of the samples ranged from $0.70-1.40 \%, 0.04-0.90 \%, 0.30-1.00 \%, 0.03-$ $0.17 \%, 1.30-2.60 \%$, and $0.50-0.80 \%$, respectively.

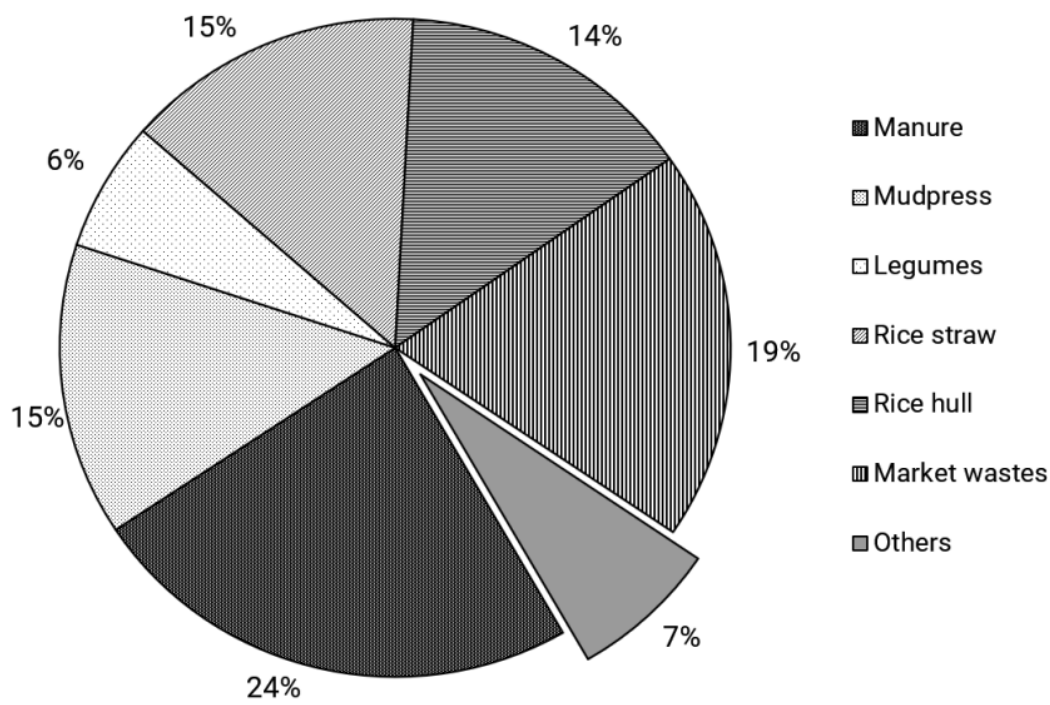

Figure 2. The average percentage (\%) of raw materials used for vermicast production in selected farms of Western Visayas, as reported by farmers

Table 1. Chemical composition of vermicasts from Western Visayas

\begin{tabular}{ccccccccc}
\hline \multirow{2}{*}{$\begin{array}{c}\text { Code } \\
\text { No. }\end{array}$} & $\mathrm{pH}$ & $\mathrm{OM}(\%)$ & \multicolumn{7}{c}{ Total (\%) } \\
\cline { 4 - 9 } & & $\mathrm{N}$ & $\mathrm{P}$ & $\mathrm{K}$ & $\mathrm{Na}$ & $\mathrm{Ca}$ & $\mathrm{Mg}$ \\
\hline 1 & 6.50 & 38.80 & 0.80 & 0.08 & 0.50 & 0.10 & 2.50 & 0.60 \\
2 & 4.70 & 41.80 & 0.90 & 0.06 & 1.00 & 0.13 & 2.30 & 0.60 \\
3 & 6.70 & 29.10 & 0.80 & 0.16 & 0.50 & 0.17 & 2.00 & 0.60 \\
4 & 7.00 & 45.40 & 1.30 & 0.34 & 1.00 & 0.09 & 1.50 & 0.50 \\
5 & 7.00 & 25.90 & 0.70 & 0.04 & 0.60 & 0.03 & 2.60 & 0.60 \\
6 & 7.60 & 36.70 & 1.40 & 0.20 & 0.30 & 0.04 & 2.40 & 0.60 \\
7 & 6.80 & 25.40 & 1.20 & 0.90 & 0.70 & 0.07 & 1.30 & 0.80 \\
\hline
\end{tabular}




\section{Chemical Composition of Reformulated Vermicasts}

Reformulation work is important to be able to know the composition of the improved products based on the locally available substrates. In this particular study, the chemical composition of the collected samples (Table 1) and effective microorganism (EM)-based fertilizer material as the commonly used and effective bio-fertilizer were compared with that of the reformulated mudpress-based vermicasts (ie, $\mathrm{OF}_{1}$ and $\mathrm{OF}_{2}$ ) (Figure 3). Chemical analyses revealed a higher total $\mathrm{N}$ content $\left(1.23-1.37 \%\right.$ ) in reformulated vermicasts (ie, $\mathrm{OF}_{1}$ and $\mathrm{OF}_{2}$ ) than the average composition of the samples from Western Visayas. However, these samples had near-neutral $\mathrm{pH}$ and high $\mathrm{OM}$ contents with relatively lower total $\mathrm{P}, \mathrm{K}$ and $\mathrm{Ca}$ content than the vermicasts from Western Visayas.

In the reformulation, Lactic Acid Bacteria (LAB), in the form of a serum produced from fermented rice wash, was added to improve the properties of casts in vermicomposting. $L A B$ are common in compost and are responsible for decomposing a variety of organic materials. According to Shrestha et al (2014) and Giassi et al (2016), as cited by Lamont et al (2017), LAB can solubilize phosphate through organic acid production. Moreover, three strains of LAB isolated from sugarcane ferment were found to have the ability to fix atmospheric N (Giassi et al 2016 as cited by Lamont et al 2017). This may explain the relatively high $\mathrm{N}$ content in vermicasts treated with LABS.

\section{Growth Performance of Corn as Affected by the Reformulated Fertilizer Materials}

The growth of the corn seedlings using different media was observed for three days after sowing (DAS). A similar appearance in height and plant vigor was observed at 7-10 DAS in all of the seedlings regardless of the medium used. A significant difference in the appearance of seedlings was observed starting from 14 DAS until 21 DAS (Figure 4). Yellowing of leaves was observed on seedlings using control medium $\left(T_{1}\right)$ as well as the seedlings treated with $E M\left(T_{3}\right)$ and vermicast derived from mudpress + cow manure + banana peelings + LABS $\left(T_{4}\right)$. At 19 DAS, a significant increase in the growth parameters was observed for all the samples except $T_{1}$ and $T_{4}$. On the other hand, the yellowing and growth rate reduction of the seedlings using both treatments $\left(T_{1}\right.$ and $\left.T_{4}\right)$ proceeded up until $21 \mathrm{DAS}$. The growth of the seedlings treated with inorganic fertilizers $\left(T_{2}\right)$ and vermicast derived from mudpress + madre de cacao + rice straw + LABS $\left(T_{5}\right)$ were relatively superior to the rest of the treatments. Furthermore, seedlings using both of these treatments were more or less comparable in terms of the growth parameters measured. The EM enriched medium produced seedlings that were neither inferior nor superior, in terms of growth, to the rest of the seedlings using the other treatments. The growth parameters observed throughout the experiment were consistent for all of the replicate seedlings under each treatment.

Organic fertilizer has long been used as a source of nutrients for plant growth. These nutrients are used by plants to build up tissues necessary for survival. In this study, it is evident that the fertility status of the soil plays a major role in affecting biomass production. At 17 DAS, organic fertilizer application significantly influenced the number of leaves of corn (Figure 5A). During this period, the number of leaves of 
corn seedlings in soils enriched with inorganic fertilizer $\left(T_{2}\right)$ and EM $\left(T_{3}\right)$ was significantly higher but was comparable with those seedlings grown in pots treated with vermicast derived from mudpress + madre de cacao + rice straw $+\operatorname{LABS}\left(T_{5}\right)$. At 21 DAS, seedlings treated with EM $\left(T_{3}\right)$ had the highest number of leaves among the treatments.
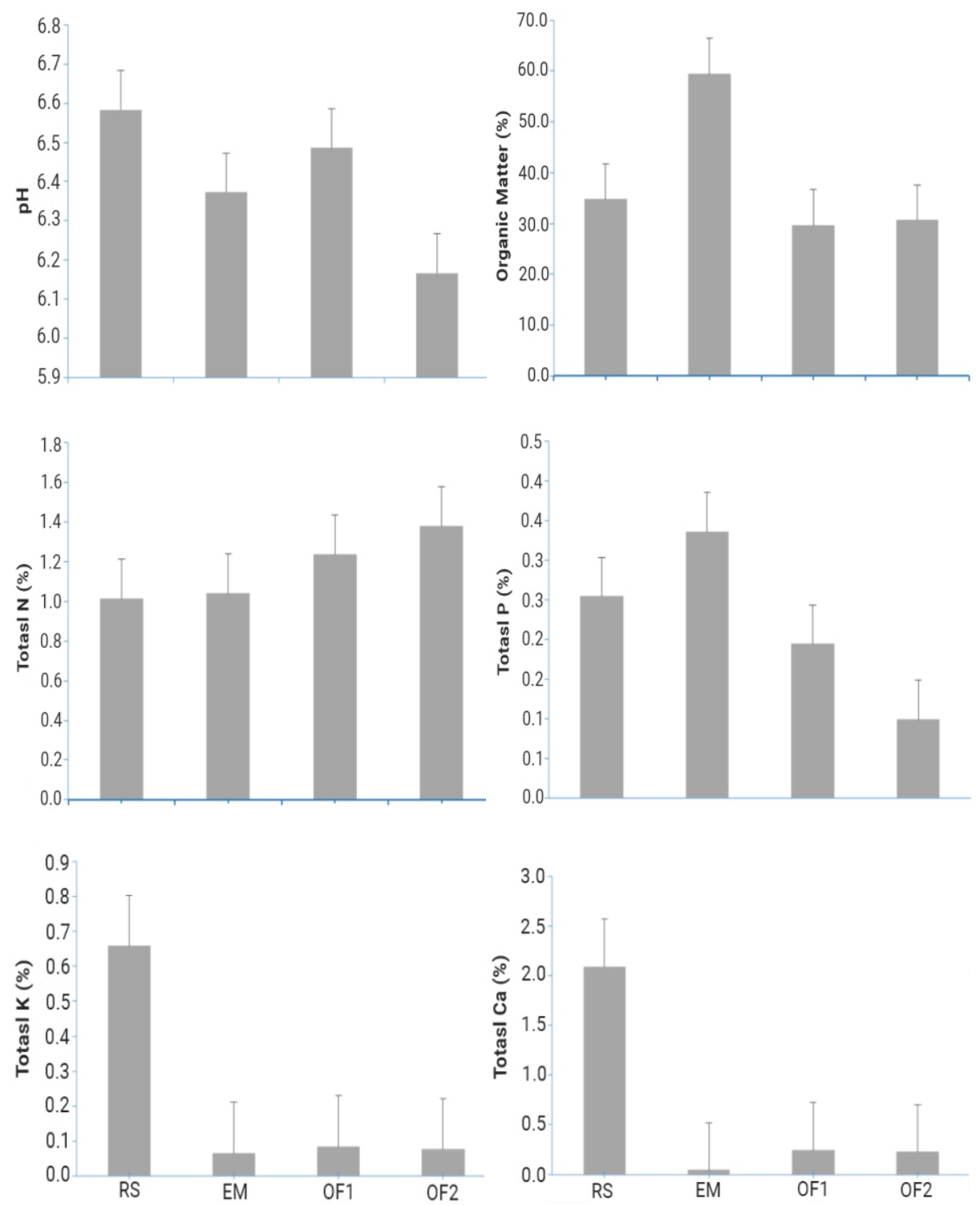

Figure 3. Chemical composition of collected vermicast samples (average of each parameter from Table 1), effective microorganisms (EM), and reformulated organic fertilizers $\left(\mathrm{OF}_{1}\right.$ and $\mathrm{OF}_{2}$ ) 
application of vermicast derived from mudpress + madre de cacao + rice straw + LABS $\left(T_{5}\right)$ but was comparable with those seedlings grown with inorganic fertilizer $\left(T_{2}\right)$. Apart from the seedlings grown using the control medium, soil with added vermicast derived from mudpress + cow manure + banana peelings + LABS $\left(T_{4}\right)$ produced relatively inferior seedlings than the rest of the treatments.

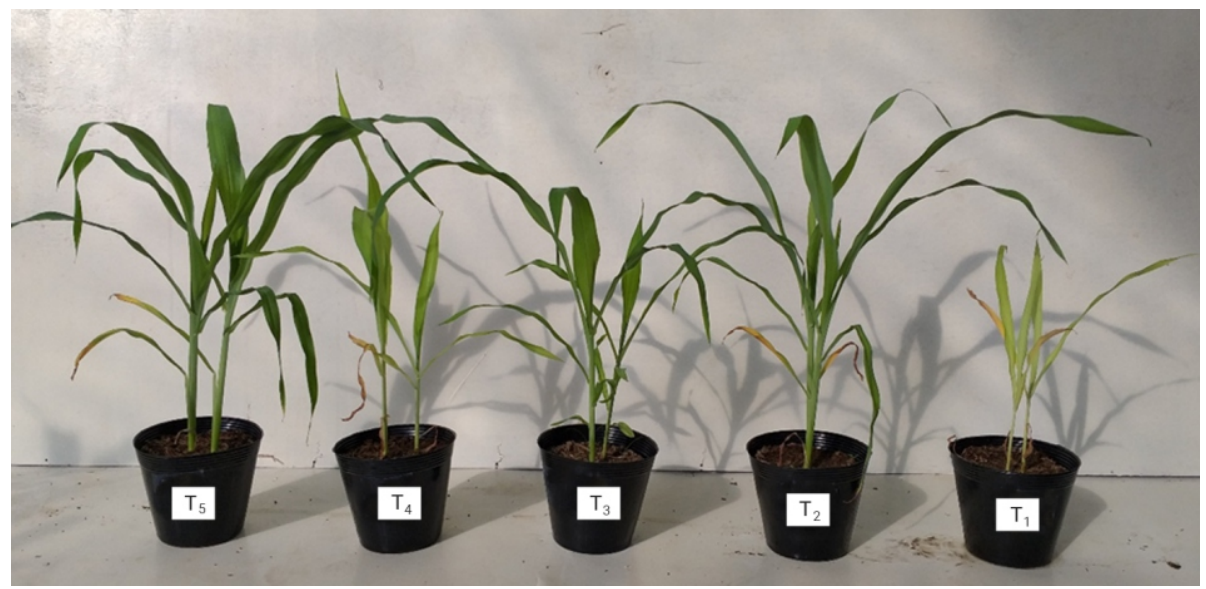

Figure 4. The visual appearance of corn seedlings grown under different reformulated organic fertilizers at 21 days after sowing. ( $T_{1}-$ control, $T_{2}$ - inorganic fertilizer, $T_{3}-E M, T_{4}-$ vermicast derived from mudpress + cow manure + banana peelings + LABS, $T_{5}$ - vermicast derived from mudpress + madre de cacao + rice straw + LABS).

On the other hand, at 10 to 21 DAS, plant height was significantly affected by the treatments used, with $T_{5}$ having the highest value compared to the rest of the treatments (Figure 5B). This study supports the work of Canatoy (2018) on the effects of vermicast on the growth and yield of sweetcorn wherein the height of corn at 20 DAS was significantly affected by the application of vermicast. Likewise, at 14 to 21 DAS, the height of corn seedlings were significantly taller in pots with the application of vermicast derived from mudpress + madre de cacao + rice straw + LABS $\left(T_{5}\right)$ but was comparable with those seedlings grown with inorganic fertilizer $\left(T_{2}\right)$. Apart from the seedlings grown using the control medium, soil with added vermicast derived from mudpress + cow manure + banana peelings $+\operatorname{LABS}\left(T_{4}\right)$ produced relatively inferior seedlings than the rest of the treatments.

Furthermore, at 10 to 21 DAS, the leaf area of the corn seedlings was significantly affected by the application of organic fertilizer (Figure 5C). During that period, the leaf area of the seedlings treated with vermicast derived from mudpress + madre de cacao + rice straw + LABS $\left(T_{5}\right)$ was significantly higher than the rest of the treatments.

Organic fertilizer application has a significant effect on the crop growth and yield as documented by several studies. In this study, regardless on the nature of the organic fertilizer applied, the effect on the growth parameters (ie, number of leaves, height and leaf area) was comparable to inorganic fertilizer. According to the study by Lina et al (2014) on corn grown on marginal uplands, better growth performance was obtained from plants treated with inorganic fertilizer following the recommended rate (90-60-60kg N, P, K ha ${ }^{-1}$ ) than the rest of the plants under solo application of organic fertilizer (ie, chicken dung and vermicast). However, the increase in yield and 
other growth parameters of corn using inorganic fertilizer application was not significantly different from those plants using a combined application of inorganic and organic fertilizers of both chicken dung and vermicast.
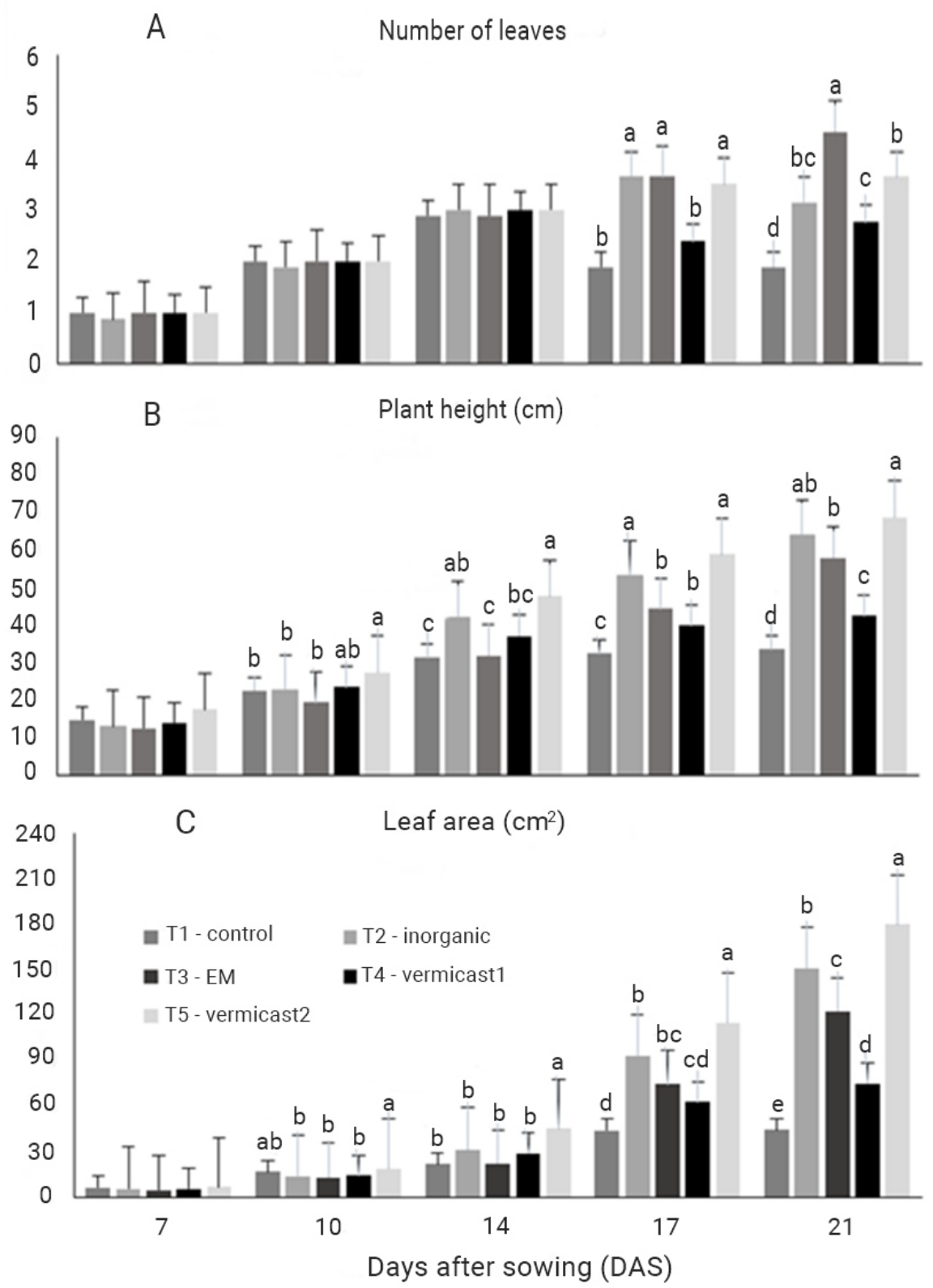

Figure 5. Number of leaves (a), height (b) and leaf area (c) of corn grown under different reformulated organic fertilizers from 7 to 21 days after sowing. (Vermicast 1 - mudpress + cow manure + banana peelings + LABS, vermicast 2 - mudpress + madre de cacao + rice straw $+L A B S)$. Column represents treatment means $\pm S E(n=3)$. Means followed by different letters within the same day differ significantly $(p \leq 0.05)$ 


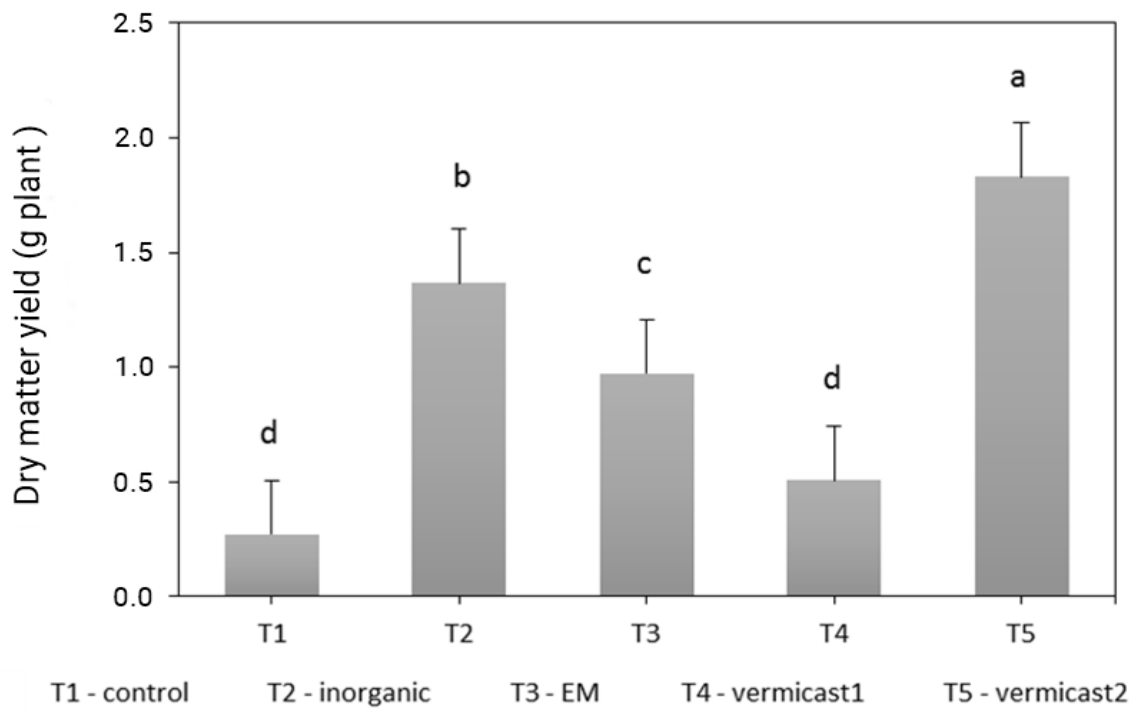

Figure 6. Dry matter yield (g plant ${ }^{-1}$ ) of corn grown under different reformulated organic fertilizers. $\left(T_{1}-\right.$ control, $T_{2}$ - inorganic, $T_{3}-E M, T_{4}$ - vermicast derived from mudpress + cow manure + banana peelings $+\mathrm{LABS}, \mathrm{T}_{5}$ - vermicast derived from mudpress + madre de cacao + rice straw + LABS). Column represents treatment means $\pm S E(n=3)$. Treatments with the same letter are not statistically different at $5 \%$ level of significance

Plant dry matter results from the integration of all plant processes and is considered to be the most important parameter in the study of plant canopies. The dry matter production of corn seedlings was significantly affected by the different organic fertilizers applied. In this study, the highest dry matter yield (1.83g plant $\left.{ }^{-1}\right)$ was obtained from the seedlings grown under soil enriched with vermicast derived from mudpress + madre de cacao + rice straw + LABS $\left(T_{5}\right)$ (Figure 6). The increase in the dry matter content of corn under $T_{5}$ could be attributed to its nutrient content. Apart from internal factors, dry matter production of plants is also influenced by edaphic factors, fertility status specifically. Nutrients including N, P and K are mainly taken up by the plants during vegetative growth to facilitate photosynthetic activity thus, increasing biomass production (Roy 2006). Madre de cacao, commonly known as kakawate, has long been used as a green manure for crop production. IIRR and NAPC (2016) suggested that green leaves obtained from 600 kakawate trees are known to provide enough nutrients for a hectare of paddy rice. Moreover, liquid fertilizer from kakawate leaves contains higher $\mathrm{N}$ (ie, $181 \mathrm{mg} \mathrm{kg}^{-1}$ ) and $\mathrm{K}$ (ie, $218.5 \mathrm{mg} \mathrm{kg}^{-1}$ ) than cow manure with a significant content of $\mathrm{P}, \mathrm{Fe}, \mathrm{Ca}, \mathrm{Mg}$ and Zinc (Zn).

\section{CONCLUSIONS}

The chemical composition of vermicast is dependent upon the quality of the substrates used in the composting process. In this study, most vermicast samples 
with high nutrient contents were derived from mixtures of animal manure, mudpress, rice straw and market wastes. Chemical analysis revealed $\mathrm{pH}$ values ranging from 4.7-7.0 and total $\mathrm{N}, \mathrm{P}, \mathrm{K}, \mathrm{Na}, \mathrm{Ca}$ and $\mathrm{Mg}$ content ranging from $0.70-1.40 \%, 0.04-0.90 \%$, $0.30-1.00 \%, 0.03-0.17 \%, 1.30-2.60 \%$, and $0.50-0.80 \%$, respectively. The total $\mathrm{N}_{1} \mathrm{P}_{2} \mathrm{O}_{5}$, $\mathrm{K}_{2} \mathrm{O}$ of all the vermicasts produced on the selected farms fell below $4.10 \%$, which is lower than what is recommended by the Philippine National Standards (PNS). Moreover, in the reformulation, reformulated vermicasts had a higher total $\mathrm{N}$ content but relatively lower total $\mathrm{P}, \mathrm{K}, \mathrm{Na}, \mathrm{Ca}$ and $\mathrm{Mg}$ content than vermicasts from selected farms in Western Visayas.

The application of vermicast had a significant effect on the growth of corn seedlings. Soil enriched with vermicast derived from mudpress + madre de cacao + rice straw + LABS performed the best in terms of growth parameters (ie, number of leaves, plant height and leaf area) and dry matter yield than the rest of the treatments involved. The growth and the dry matter production of this treatment were even better than those seedlings using inorganic fertilizer. This implies that, other than inorganic fertilizer, vermicast enriched with LABS provides great potential for crop growth improvement.

\section{RECOMMENDATIONS}

For further improvement of the study, the following recommendations could be applied: (1) for chemical analysis, heavy metals could also be included to determine whether the material produced had passed the standard for the heavy metal content of organic fertilizer, (2) other than garden soil, the set-up could also include acidic soil to illustrate the response of corn under vermicast enriched soil in the marginal uplands, (3) the study could be extended for a longer period for the yield and yield components of the corn to be included, (4) plant tissue analysis could also be included to determine the nutrient uptake of corn using different fertilizer materials, and (5) soil analysis could also be done.

\section{REFERENCES}

Aboukila EF, Nassar IN, Rashad M, Hafez M \& Norton JB. 2018. Reclamation of calcareous soil and improvement of squash growth using brewers'spent grain and compost. Journal of Saudi Society of Agriculture Sciences 17(4):390-397

Aviles MA Jr. 2010. Integration of BIO-N with vermicast and inorganic fertilizers as nutrient management for corn production (Undergraduate thesis). VSU, Visca, Baybay City, Leyte

Bureau of Soils and Water Management (BSWM). 2014. Updated manual for soil, water, plant tissue and fertilizer analysis. Department of Agriculture. Laboratory Service Division

de la Cruz NE, Aganon CP, Patricio MG, Romero ES, Lindain SA \& Galindez JL. 2008. Production of organic fertilizer from solid waste and its utilization in intensive organic-based vegetable production and for sustaining soil health and productivity. Proceedings of the International Workshop on Sustained Management of the Soil-Rhizosphere System for Efficient Crop Production and Fertilizer Use, 16-20 October 2006, Land Development Department, Bangkok, Thailand 
Deshev MG, Desheva GN \& Stamatov SK. 2020. Germination and early seedling growth characteristics of arachis hypogaea L. under salinity (NACL) stress. Agriculturae Conspectus Scientificus 85(2):113-121

Canatoy RC. 2018. Effects of vermicompost on the growth and yield of sweet corn in Bukidnon, Philippines. Asian Journal of Soil Science and Plant Nutrition 3(2):1-8

Hafez M, Popov Al \& Rashad M. 2021. Integrated use of bio-organic fertilizers for enhancing soil fertility-plant nutrition, germination status and initial growth of corn (Zea mays L.). Environmental Technology and Innovation 21(1):1-31

International Institute Of Rural Reconstruction (IIRR) and National Anti-poverty Commission (NAPC). 2016. Integrated community food production: a compendium of climate-resilient agriculture options. Copenhagen, Denmark: CGIAR Research Program on Climate Change, Agriculture and Food Security (CCAFS)

International Soil Reference and Information Centre (ISRIC). 2002. In van Reeuwijk LP (ed) Procedure for Soil Analysis (6th edn). Wageningen, Netherlands

Karmegam N and Daniel T. 2009. Effects of application of vermicasts as layering media for an ornamental plant, Codiaeum variegatum (L.) BI. Dynamic Soil, Dynamic Plant. Global Science Books

Lamont JR, Wilkins O, Bywater-Ekegard M \& Smith DL. 2017. From yogurt to yield: potential applications of lactic acid bacteria in plant production. Soil Biology and Biochemistry 111:1-9

Lina SB, Maranguit DS, Asio VB, Sabijon JR, Demain KLB \& Bolledo AB. 2014. Growth performance of corn as influenced by the combined application of organic and inorganic fertilizers in a marginal upland soil. Annals of Tropical Research 36(Supplement):16-29

Nelson DW and Sommers LE. 1982. Methods of soil analysis Part 2. American Society of Agronomy-Soil Science Society of America, 677 South Segoe Road, Madison, WI 53711, USA

Philippine Council For Agriculture And Resource Research (PCARR). 1980. Standard methods of analysis for soil, plant tissue, water and fertilizer. Farm and System Research Division. Philippine Council for Agriculture and Resource Research, Los Baños, Laguna, Philippines

Priya S and Santhi S. 2014. Effects of vermicomposts on the growth of amaranthus plants and soil fertility. Pelagia Research Library. Advances in Applied Science Research 5(1):231-240

Roy RN. 2006. Plant nutrition for food security: a guide for integrated nutrient management. FAO Fertilizer and Plant Nutrition Bulletin 16:25-28 